\title{
Déterminisme génétiQue de la précocité sexuelle, DU TAUX D'OVULATION ET DU NOMBRE D'EMBRYONS CHEZ LA TRUIE : HÉRITABILITÉ, EFFET D'HÉTÉROSIS
}

\author{
C. LEGAULT \\ Station de Génétique quantitative et appliquée \\ Centre national de Recherches zootechniques, I. N.R. A., \\ 78350 Jouy en Josas

\section{RÉSUMÉ}

L'analyse génétique du poids, de l'âge, du taux d'ovulation et du nombre d'embryons conçus au premier œestrus a été effectuée sur des données recueillies sur six séries successives d'animaux nés respectivement au mois d'août des années 1966 à I97I, alimentés ad libitum et soumis au contrôle quotidien des chaleurs dès le poids vif de 70 kilogrammes.

Les composantes de la variance des deux premières variables ont d'abord été estimées à partir des informations recueillies sur 649 truies de race pure (dont 6or Large-White et 48 Landrace nées uniquement en $197 \mathrm{I})$, filles de 65 verrats et de 233 truies mères. Cet effectif était réduit respectivement à 474 pour le taux d'ovulation et à 304 pour le nombre d'embryons.

L'effet combiné de l'année et de la race est significatif sur le poids et l'âge à la puberté dont il explique respectivement I5,9 p. Ioo et $\mathrm{r}_{3}, \mathrm{I}$ p. roo de la variance. L'effet "père " est significatif sur les trois premières variables dont il explique respectivement 9,9 p. IOO, Io, I p. IOO et 5,7 p. Ioo de la variance. Enfin, l'effet "mère " n'est significatif que sur les deux variables représentatives de la précocité sexuelle dont il explique respectivement $22,6 \mathrm{p}$. 1oo et $20 \mathrm{p}$. Ioo de la variance. Les estimations de l'héritabilité des quatre variables précisées sont respectivement : 0,$44 ; 0,46 ; 0,23$ et 0,12 .

Les estimations de l'effet d'hétérosis ont été obtenues en comparant les performances des $24 \mathrm{I}$ truies de race pure contrôlées en I97 I et 1972 à celles de 329 truies contemporaines issues du croisement : verrat Landrace $\times$ truie Large-White. Voisin de zéro pour le poids à la puberté, l'effet d'hétérosis est de l'ordre de 8 à ro p. too pour l'âge à la puberté, de 3,5 p. roo pour le taux d'ovulation et de 8 p. Ioo sur le nombre d'embryons.

Le taux d'ovulation est trop peu héritable et relié par une corrélation trop faible avec le nombre d'embryons pour que l'on puisse envisager l'amélioration génétique de cette seconde variable par la sélection de la première. Enfin, l'âge à la puberté est suffisamment héritable pour se prêter à une sélection efficace; cependant une amélioration plus rapide de ce caractère est obtenue par utilisation des croisements. 


\title{
SUMMARY
}

GENETIC DETERMINISM OF SEXUAL PRECOCITY, OVULATION RATE

AND NUMBER OF EMBRYOS IN THE SOW : HERITABILITY, HETEROSIS EFFECT

Genetic analysis of the weight, age, ovulation rate and number of embryos at the first cestrus has been made on data obtained from six successive series of animals born in August from I 966 to $197 \mathrm{I}$, respectively, fed ad libitum and submitted to daily heat controls from $70 \mathrm{~kg}$ live weight.

The components of the variance of the first two variables were estimated on the basis of informations collected from 649 purebred sows (60I Large-White and $4^{8}$ Landrace sows born only in I97I), daughters of 65 sires and 233 dams. This number of animals was reduced to 474 for the ovulation rate and $30_{4}$ for the number of embryos, respectively.

The combined effect of year and breed on weight and age at puberty was significant and explained I5.9 and I3.I p. Ioo respectively of the variance. The "sire "effect was significant on the first three variables and explained 9.9, ro. I and $5.7 \mathrm{p}$. Too respectively of the variance. Finally, the "dam " effect was only significant on the two variables representative of sexual precocity and explained $\mathbf{2 2 . 6}$ and 20.0 p. Ioo respectively of the variance. Estimation of the heritability of the four precited variables were : $0.44,0.46,0.23$ and 0.12 , respectively.

Estimations of heterosis effect were made by comparing performances of $24 \mathrm{I}$ purebred sows controlled in 1971 and 1972 to those of 329 contemporary crossbred animals : Landrace male $\times$ Large-White female. Almost inexistent for the weight at puberty, the heterosis effect was about 8 to Io $\mathrm{p}$. Ioo for the age at puberty, $3.5 \mathrm{p}$. Ioo for the ovulation rate and 8 p. Ioo for the number of embryos.

The ovulation rate being not heritable enough and too slightly correlated with the number of embryos it is not possible to obtain a genetic improvement of the second variable by selection of the first one. Finally, the age at puberty is sufficiently heritable to be fitted for efficient selection; however, a more rapid improvement of this character can be obtained by crossbreeding.

\section{EFFET DU CROISEMENT SUR LE TAUX DE RÉUSSITE DE L'INSÉMINATION ARTIFICIELLE CHEZ LA TRUIE. INCIDENCE ÉCONOMIQUE}

\author{
C. LEgAULT, J. GRUAND et J.-P. PROVOST \\ Station de Génétique quantitative et appliquée \\ Centre national de Recherches zootechniques, I. N. R. A., \\ 78350 Jouy en Josas
}

\section{RÉSUMÉ}

Le taux de réussite de l'insémination artificielle à la puberté de I 44 jeunes truies de race pure (dont 96 Large-White et 48 Landrace) et de II 4 jeunes truies issues du croisement mâle Landrace $\times$ femelle Large-White observés dans le cadre d'une étude expérimentale sont respec- 